\title{
Renovation of industrial territories in single industry towns on the basis of industrial parks
}

\author{
Vladimir Filatov ${ }^{1, *}$, Zhanna Dibrova ${ }^{1}$, Natalya Zhukova $^{1}$ \\ ${ }^{1}$ Moscow State University of Technology and Management. K.G. Razumovsky, Zemlyanoy val st., \\ 73, 109004, Moscow, Russia
}

\begin{abstract}
The issues of renovation of industrial territories in single industry towns on the basis of industrial parks at the current stage are considered in this paper. The development of a new service industry industrial parks - has started in Russia less than 10 years ago and gradually acquires a systemic character. However, the gap with the countries of America, Europe and Asia remains very significant. Dozens of new initiatives to create industrial parks of various forms of ownership have appeared in Russia in recent years. However, most areas of Russian industrial parks remain vacant against the backdrop of existing unmet demand for prepared sites and related services for the location of manufacturing plants. One of the main problems of the industry is that the quality of many industrial park projects announced in the country does not meet the requirements of investors - potential residents.
\end{abstract}

\section{Introduction}

The issues of renovation of industrial territories are highly relevant for many Russian towns. In the conditions of the necessity to search for new drivers for the economic growth of towns, to improve the quality of the urban environment, and to increase the efficiency of the use of urban areas, an important task of finding and elaborating of innovation models for the development of industrial zones arises. In international practice, a rich experience of the revitalization of industrial and urban areas has been accumulated [1].

However, such complexes were not created in Russia until recently due to the long payback periods of such innovative projects and the ambiguities with the filling of the project by residents. Such areas are of interest to the companies that do not plan to build their own production facilities due to limitations in the starting dates of supply or because the financial model of the business doesn't provide for construction costs.

\section{Materials and methods}

There are several classifications of industrial parks. Depending on the formation of productive capacity, industrial parks are classified as greenfield or brownfield. In the first

\footnotetext{
*Corresponding author: filatov_vl@mail.ru
} 
case, a resident of an industrial park is given a land plot on which he independently builds production or warehouse facilities. In the second case, the resident acquires or rents readymade production or warehouse buildings for the implementation of his project [2].

Today, there is a huge need for the support and development of industrial parks in Russia. The state starts to take care of this by providing subsidies, tax incentives, and special loan programs. As a part of the state program of the Russian Federation "Industrial development and improvement of its competitiveness", the subprogram "Industrial parks" was created [3]. On the basis of the resolution of the Government of the Russian Federation No. 16051, there are definitions of trading estates, industrial parks, agro-industrial parks, private industrial parks and technoparks (Figure 1).

\begin{tabular}{|c|c|c|}
\hline \multicolumn{3}{|c|}{$\begin{array}{c}\text { Trading estates, industrial parks, agro-industrial parks, private industrial parks and } \\
\text { technoparks }\end{array}$} \\
\hline $\begin{array}{l}\text { Trading estate, industrial } \\
\text { park, agro-industrial park } \\
\text { - a complex of real estate } \\
\text { and infrastructure facilities, } \\
\text { land plots, administrative, } \\
\text { production, warehouse and } \\
\text { other premises that support } \\
\text { the operation of the park, } \\
\text { intended for production by } \\
\text { small and medium-sized } \\
\text { enterprises and provision of } \\
\text { conditions for their effective } \\
\text { operation, managed by a } \\
\text { single operator } \\
\text { (management company) }\end{array}$ & $\begin{array}{l}\text { Private industrial park - a complex } \\
\text { of real estate and infrastructure } \\
\text { facilities, land plots, administrative, } \\
\text { production, warehouse and other } \\
\text { premises that support the operation } \\
\text { of the industrial park, intended for } \\
\text { production by small and medium- } \\
\text { sized enterprises and the provision of } \\
\text { conditions for their effective } \\
\text { operation, managed by a single } \\
\text { operator (management company) - a } \\
\text { legal entity in the authorized capital } \\
\text { of which the Russian Federation, the } \\
\text { federal subject of the Russian } \\
\text { Federation and (or) the municipal } \\
\text { entity do not participate. }\end{array}$ & $\begin{array}{l}\text { Technopark - a } \\
\text { complex of real estate } \\
\text { objects created for the } \\
\text { implementation of } \\
\text { activities of small and } \\
\text { medium-sized } \\
\text { enterprises in the field of } \\
\text { high technology, } \\
\text { consisting of land plots, } \\
\text { office buildings, } \\
\text { laboratory and } \\
\text { production facilities, } \\
\text { engineering, } \\
\text { transportation, } \\
\text { residential and social } \\
\text { infrastructure }\end{array}$ \\
\hline \multicolumn{3}{|c|}{ Performance indicators of subsidies } \\
\hline $\begin{array}{l}\text { The number of small and } \\
\text { medium-sized enterprises } \\
\text { (SMEs) located on the } \\
\text { territory of the industrial } \\
\text { park }\end{array}$ & $\begin{array}{l}\text { 1. Total revenue of small and medium- } \\
\text { sized enterprises (SMEs) - residents of } \\
\text { the industrial park } \\
\text { 2. The number of small and medium- } \\
\text { sized enterprises (SMEs) located on } \\
\text { the territory of the industrial park }\end{array}$ & $\begin{array}{l}\text { The number of small and } \\
\text { medium-sized enterprises } \\
\text { (SMEs) located on the } \\
\text { territory of the } \\
\text { technopark }\end{array}$ \\
\hline
\end{tabular}

Fig. 1. Definitions of the content of trading estates, industrial parks, agro-industrial parks, private industrial parks and technoparks.

As a measure of state support, about 600 million rubles were allocated in 2014. More than 1 billion rubles was allocated annually for the period from 2015 to 2017 . The Rules were established for granting subsidies from the federal budget to Russian organizations for reimbursing part of its loan interest expenses received in Russian credit institutions and the state corporation "Bank for Development and Foreign Economic Affairs (Vnesheconombank)" in 2013-2016 for the capital construction of infrastructure facilities and industrial parks as a part of the subprogram "Industrial parks" of the state program of the Russian Federation "Industrial development and improvement of its competitiveness" (Table 1). 
Table 1. Instruments of state support for the creation of trading estates, industrial parks, agroindustrial parks, private industrial parks and technoparks*.

\begin{tabular}{|c|c|}
\hline cial instruments & cuments \\
\hline $\begin{array}{l}\text { - The national standard of the Russian } \\
\text { Federation "Industrial parks. Requirements" } \\
\text { (GOST R 56301-2014, implemented on } \\
\text { September 1, 2015) } \\
\text { - Methodological recommendations for the } \\
\text { creation, operation and development of } \\
\text { industrial parks and technoparks (detailed road } \\
\text { map for the creation of the park, including } \\
\text { description of the requirements of regulatory } \\
\text { documents and examples of their completion) } \\
\text { - Requirements for industrial parks, } \\
\text { management companies of industrial parks, and } \\
\text { the procedure for the certification of parks } \\
\text { (OGRF No.794 of August 4, 2015, the } \\
\text { beginning of the action is January, 1, 2016) } \\
\text { - Geographic information system of } \\
\text { industrial parks, which provides the investor } \\
\text { with the opportunity of express assessment of } \\
\text { the site for the location of manufacturing plant } \\
\text { (http://www.gisip.ru/) }\end{array}$ & $\begin{array}{l}\text { - Granting subsidies from the federal } \\
\text { budget to park management companies to } \\
\text { reimburse part of its loan interest expenses } \\
\text { received from Russian credit institutions } \\
\text { (Order of the Government of the Russian } \\
\text { Federation (OGRF) No.831 of August, } 11 \text {, } \\
\text { 2015) } \\
\text { - Granting subsidies from the federal } \\
\text { budget to the federal subjects of the Russian } \\
\text { Federation for reimbursement of expenses for } \\
\text { creating parks infrastructure at the expense of } \\
\text { federal taxes of residents of parks (OGRF } \\
\text { No.1119 of October } 30,2014 \text { as amended by } \\
\text { OGRF No.733 of July } 18,2015 \text { ) } \\
\text { - Granting subsidies from the federal } \\
\text { budget to park management companies for } \\
\text { reimbursement of expenses for creation of } \\
\text { infrastructure for parks of the children's goods } \\
\text { industry (OGRF No.1179 of November, } 8 \text {, } \\
\text { 2014) }\end{array}$ \\
\hline
\end{tabular}

Currently, there are three main vectors in the development of industrial parks in Russia:

- improvement of their infrastructure, as well as service provided by management companies;

- quantitative growth, and if the first industrial parks were large enough (parks in the Kaluga region, in Tatarstan have hundreds of hectares), then now there are many park development projects on sites up to 100 hectares;

- development of the building concept of an industrial park near the single industry town.

\section{Results}

The average size of Russian industrial parks is about 255 hectares, but 10 of them have an area exceeding 1000 hectares. The regional Russian authorities are mainly engaged in the creation of industrial parks from scratch. These are the so-called greenfield projects. Twelve of 27 active greenfield-parks were created by the Russian authorities, the rest private developers. Among industrial parks organized on the site of existing facilities (brownfield), two parks were created by the Russian authorities and 12 are private. In regard to the projected industrial parks, the proportions are as follows: 25:19 and 4:7, respectively. Industrial parks can be universal, where enterprises are not connected by a single technological chain, and specialized ones, i.e. sectoral industrial clusters. Industrial clusters are formed mainly around anchor tenants engaged in the production of complex end products, for example, cars. Industrial parks have also appeared in the West in the last twenty years. Industrial parks are distinguished by the fact that companies gathering in them are connected by technologies and resources. It allows them to obtain better economic results while reducing the impact on the environment [4].

Table 2. SWOT- analysis of the development of small and medium-sized enterprises (SMEs) in industrial parks. 


\begin{tabular}{|l|l|l|}
\hline (Strengths) & $\begin{array}{l}- \text { outsourcing of non-production } \\
\text { functions (catering, maintenance of } \\
\text { engineering communications, warehouse } \\
\text { storage, transport services, accounting, } \\
\text { legal, marketing, etc.); }\end{array}$ & $\begin{array}{l}\text { - Absence of a ready-made } \\
\text { suitable industrial site or a significant } \\
\text { amount of investments in the } \\
\text { preparation of an industrial site in } \\
\text { comparison with the turnover of the } \\
\text { enterprise; }\end{array}$ \\
$\begin{array}{l}\text { purchase of products of a large enterprise } \\
\text { which is the anchored resident due to } \\
\text { discounts and reduced transportation costs. }\end{array}$ & $\begin{array}{l}\text { - Inaccessibility of financial } \\
\text { resources for the development of } \\
\text { production. }\end{array}$ \\
\hline (Weaknesses) & $\begin{array}{l}\text { - Assistance to the management } \\
\text { company on legal, economic and } \\
\text { organizational issues for residents, } \\
\text { including registration of ownership, } \\
\text { obtaining a building permit and an urban } \\
\text { development plan of a land plot. }\end{array}$ & $\begin{array}{l}\text { - Duration and high cost of the } \\
\text { procedure of connection to utility } \\
\text { networks; }\end{array}$ \\
$\begin{array}{l}\text { market for the sale of products or } \\
\text { obtaining materials from the large } \\
\text { industrial enterprises. }\end{array}$ \\
\hline
\end{tabular}

These barriers of development of small and medium-sized businesses increase the duration of the pre-investment and investment phase because of which most of investment projects do not reach the implementation stage (Table 2). The creation of favourable investment conditions within the industrial parks is proposed as an instrument for the development of small and medium-sized enterprises (SMEs) based on the renovation of production areas in single industry towns.

The developer or management company implements facility management, i.e. the industrial park may even have its own fire department. All positive factors are used, including the position and location of the industrial park, increasing its attractiveness and reducing its own costs for maintenance of manufacturing plants (Table 3). There is an opportunity to expand the business by opening new manufacturing plants since the lease of industrial premises on the park's territory is much lower [5].

Innovative ways to plan the territory are being introduced in many new industrial parks. In the meantime, new zoning methods are used involving the division of the territory of industrial parks into 3 functional zones (Industrial Park "Kola", "DEGA", etc.) for the placement of: multifunctional public and business complexes with trade sites; logistics and warehouse complexes, container sites; industrial buildings [6].

Table 3. Complex of the management company services: Russian and foreign experience [7].

\begin{tabular}{|c|c|c|c|c|}
\hline $\begin{array}{l}\text { Experien } \\
\text { ce }\end{array}$ & $\begin{array}{l}\text { Resident } \\
\text { policy }\end{array}$ & Basic services & \begin{tabular}{llr} 
Additional & \multicolumn{2}{c}{ services } \\
(operation & of & the \\
territory) & &
\end{tabular} & $\begin{array}{lr}\text { Advanced services } \\
\text { (development } & \begin{array}{r}\text { of } \\
\text { of } \\
\text { business }\end{array} \\
\text { residents) } & \text { of } \\
\end{array}$ \\
\hline Russian & $\begin{array}{l}\text { Medium } \\
\text { and large } \\
\text { companies } \\
; \\
\text { Subjects of } \\
\text { SMEs. }\end{array}$ & $\begin{array}{l}\text { Sale of land; } \\
\text { Lease of land; } \\
\text { Lease of industrial } \\
\text { premises; } \\
\text { Turnkey } \\
\text { construction.* }\end{array}$ & $\begin{array}{l}\text { Protection of the } \\
\text { territory; } \\
\text { Cleaning; } \\
\text { Maintenance and } \\
\text { operation of public } \\
\text { facilities; } \\
\text { Logistics, } \\
\text { Transportation.** }\end{array}$ & $\begin{array}{l}\text { Single } \\
\text { system. }\end{array}$ \\
\hline Foreign & $\begin{array}{l}\text { Large, } \\
\text { medium } \\
\text { and small } \\
\text { companies } \\
; \\
\text { Subjects of } \\
\text { SMEs.* }\end{array}$ & $\begin{array}{l}\text { Sale of land; } \\
\text { Sale of industrial } \\
\text { premises; } \\
\text { Lease of industrial } \\
\text { premises; } \\
\text { Turnkey } \\
\text { construction. }\end{array}$ & $\begin{array}{l}\text { Protection of the } \\
\text { territory; } \\
\text { Cleaning; } \\
\text { Maintenance and } \\
\text { operation of public } \\
\text { facilities; } \\
\text { IT services; Logistic; }\end{array}$ & $\begin{array}{l}\text { Single Window } \\
\text { system; } \\
\text { training / retraining } \\
\text { of personnel; sports } \\
\text { objects; objects of } \\
\text { common use; R \& } \\
\text { D services; }\end{array}$ \\
\hline
\end{tabular}




\begin{tabular}{|l|l|l|l|}
\hline & & Transport; Catering.** & $\begin{array}{l}\text { Cluster } \\
\text { development } \\
\text { centers; }\end{array}$ \\
& & & $\begin{array}{l}\text { Distribution centers; } \\
\text { Export development } \\
\text { centers. }\end{array}$ \\
\hline
\end{tabular}

*-Advantage in development **- Experience is equivalent

Another particularity of the Russian management of industrial parks was the creation of Development Corporations, which are represented almost in all regions today. The tasks of corporations include the development of investment programs, the search for investors for industrial parks operating in the region, and a number of other functions (Figure 2). The occupancy rate of any industrial park largely depends on the effective work of Development Corporations.

Development fund of single industry towns;
SME support programs;
Industrial Development Fund;
Russian Direct Investment Fund;
EXAR - Export Insurance Agency of Russia

\begin{tabular}{|l|}
\hline Emerging problems: \\
- No experience in \\
preparation of \\
documents; \\
- Participation in a \\
large number of federal \\
meetings is required; \\
- Lack of time for \\
getting into routine \\
procedures, etc. \\
\hline
\end{tabular}
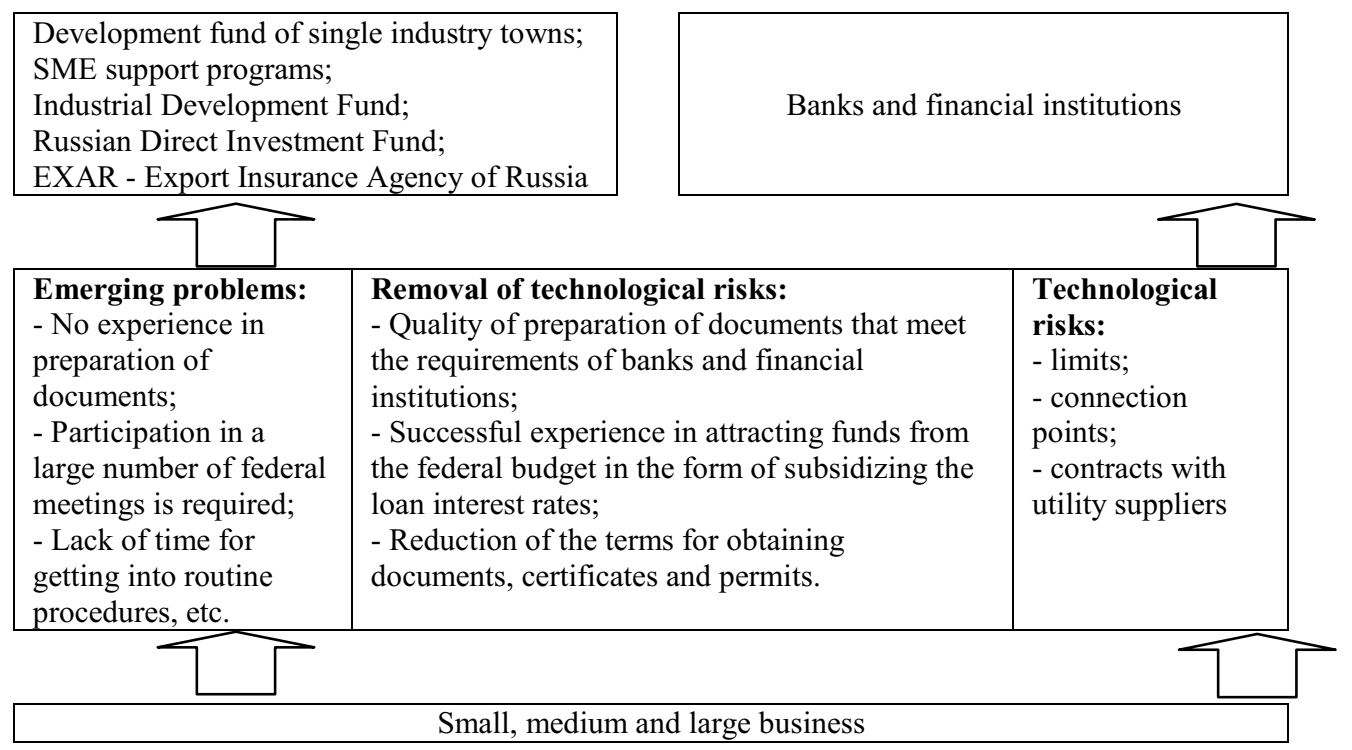

Fig. 2. Structural-logical scheme of interaction of the Development Corporation with financial institutions.

However, the mechanical creation of a development corporation is not enough. It is necessary that all development institutions of the region work coherently - the ministries and departments coordinate their plans taking into account the interests of each of the projects of industrial parks in single industry towns and nearby suburban areas. A capable team with project management should be created. As a result of such support of projects, all regional management institutions have succeeded in organizing the industrial parks in the following regions: Kaluga, Ulyanovsk, Rostov regions and the Republic of Tatarstan (Table 4).

Table 4. Financed private industrial parks*.

\begin{tabular}{|l|l|l|lll|}
\hline № & $\begin{array}{l}\text { Federal subject of the } \\
\text { Russian Federation }\end{array}$ & $\begin{array}{l}\text { Year and } \\
\text { volume of } \\
\text { financing, } \\
\text { million rubles }\end{array}$ & Financed works on the object & \\
\hline 1 & $\begin{array}{l}\text { Voronezh region } \\
\text { (Industrial } \\
\text { "Perspective") }\end{array} \quad$ park & $\begin{array}{l}2013-2014 \\
(65,5)\end{array}$ & $\begin{array}{l}\text { Building of on-site electric power } \\
\text { networks and roads }\end{array}$ & & \\
\hline
\end{tabular}




\begin{tabular}{|c|c|c|c|}
\hline 2 & 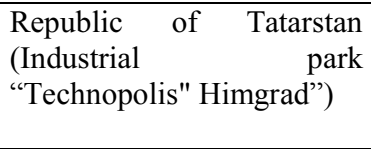 & $\begin{array}{l}2013 \\
(120,0)\end{array}$ & $\begin{array}{l}\text { External networks of electric power and } \\
\text { water supply, sewerage, heat and gas } \\
\text { supply to the production and warehouse } \\
\text { building }\end{array}$ \\
\hline 3 & $\begin{array}{lr}\text { Republic of } & \text { Tatarstan } \\
\text { (Industrial } \\
\text { "Tyulyachi") }\end{array}$ & $\begin{array}{l}2014 \\
(140,0)\end{array}$ & $\begin{array}{l}\text { Building of energy and engineering } \\
\text { infrastructure (household and storm water } \\
\text { drainage, water supply networks), } \\
\text { transport infrastructure (roads) }\end{array}$ \\
\hline 4 & $\begin{array}{l}\text { Republic of Tatarstan } \\
\text { (Kamsky Industrial park } \\
\text { "Master") }\end{array}$ & $\begin{array}{l}2013-2015 \\
(150,0)\end{array}$ & $\begin{array}{l}\text { Reconstruction of the production } \\
\text { building, repair of roof }\end{array}$ \\
\hline 5 & $\begin{array}{l}\text { Republic of Tatarstan } \\
\text { (Industrial park "Sokury") }\end{array}$ & $\begin{array}{l}2015 \\
(20,0)\end{array}$ & $\begin{array}{l}\text { Development of engineering and } \\
\text { transport infrastructure, drilling of a well, } \\
\text { construction of a water tower and water } \\
\text { line networks }\end{array}$ \\
\hline 6 & $\begin{array}{l}\text { Republic of Tatarstan } \\
\text { (Industrial park "Kazan } \\
\text { Synthetic Rubber Plant") }\end{array}$ & $\begin{array}{l}2015 \\
(47,02)\end{array}$ & $\begin{array}{l}\text { Construction of water and wastewater } \\
\text { treatment facilities }\end{array}$ \\
\hline 7 & $\begin{array}{l}\text { Udmurt } \\
\text { (Industrial park "Razvitie" } \\
\text { ("Development")) }\end{array}$ & $\begin{array}{l}2015 \\
(80,00)\end{array}$ & $\begin{array}{llll}\begin{array}{l}\text { Industrial equipment } \\
\text { purpose }\end{array} & & & \\
\end{array}$ \\
\hline 8 & $\begin{array}{l}\text { Khabarovsk Krai (Industrial } \\
\text { park "Avangard") }\end{array}$ & $\begin{array}{l}2015 \\
(49,00)\end{array}$ & High pressure gas pipeline \\
\hline
\end{tabular}

As a part of the state program for the development of single industry towns, such industrial parks as parks in Kaluga ("Grabtsevo"), where the "Volkswagen" plant is located, have been created and are being created. The total area of the park is more than seven hundred and thirty hectares, and only about seventy hectares are still free. There is a well-developed park in the territory of the special economic zone - the Baltic Industrial Park (Kaliningrad). Even its own port complex will soon start to operate there. Experts explain such successes by the fact that there is an obligatory and the most serious support of the state. Local projects supported only at the regional level are developing not so quickly and not on such a large scale [8].

Prospects for the development of industrial parks in the Republic of Bashkortostan (Table 5):

- the effect of the creation of 37 industrial parks on the territory of the Republic of Bashkortostan (taking into account the occupancy of $60-70 \%$ by residents):

- an estimate of the total annual volume of industrial production (revenues of enterprises from production) is about 45 million rubles.

- the total amount of accrued investment income for the development of the network of industrial parks will be about 82 million rubles, including the following:

- investments in infrastructure - about 13 million rubles.

- investments in production - about 69 million rubles.

- more than 5,000 workplaces will be created by residents of industrial parks.

Table 5. Projects of industrial parks in the Republic of Bashkortostan [9].

\begin{tabular}{|l|l|l|l|l|l|}
\hline № & Name, location & Type & Area & Transport infrastructure: & $\begin{array}{l}\text { Engineering } \\
\text { infrastructure: }\end{array}$ \\
\hline
\end{tabular}




\begin{tabular}{|c|c|c|c|c|c|}
\hline 1 & $\begin{array}{l}\text { Industrial park } \\
\text { "Ufimsky" } \\
\text { Ufimsky district }\end{array}$ & \multirow[t]{2}{*}{ 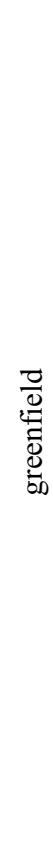 } & 298 ha & $\begin{array}{l}\text { - direct access to the federal } \\
\text { highway M-5 "Ural" and } \\
\text { access to the branch line of } \\
\text { the railway Ufa-Chelyabinsk } \\
\text { - } 43 \mathrm{~km} \text { to the International } \\
\text { Airport "Ufa" } \\
-28 \mathrm{~km} \text { to the river port of } \\
\text { Ufa. }\end{array}$ & $\begin{array}{l}\text { - gas supply - } 18 \\
000 \text { cubic } \\
\text { meters/ hour } \\
\text { - electric power } \\
\text { supply - } 46 \mathrm{MW} \\
\text { - water supply - } \\
2,030 \text { cub. m / } \\
\text { day } \\
\text { - centralized } \\
\text { sewerage, } \\
\text { wastewater } \\
\text { treatment plants } \\
\text { - } 148 \text { cub.m / } \\
\text { hour }\end{array}$ \\
\hline 2 & $\begin{array}{l}\text { Industrial park } \\
\text { "Sterlitamaksky" } \\
\text { Sterlitamaksky } \\
\text { district }\end{array}$ & & 211 ha & $\begin{array}{l}\text { 0,5 km to the Kuibyshev } \\
\text { Railway; } \\
-4,5 \mathrm{~km} \text { to the highway R- } \\
240 \text { "Ufa-Orenburg" } \\
-120 \mathrm{~km} \text { to the federal } \\
\text { highway M-5 "Ural", } 140 \mathrm{~km} \\
\text { - to the federal highway M-7 } \\
\text { "Volga" } \\
\text { - } 98 \mathrm{~km} \text { to the International } \\
\text { Airport "Ufa" }\end{array}$ & $\begin{array}{l}\text { - the plot share } \\
\text { borders with the } \\
\text { Novo- } \\
\text { Sterlitamak } \\
\text { CHP. }\end{array}$ \\
\hline 3 & $\begin{array}{l}\text { Industrial park } \\
\text { "KhimTerra", } \\
\text { Blagoveshchensky } \\
\text { district }\end{array}$ & \multirow{2}{*}{ 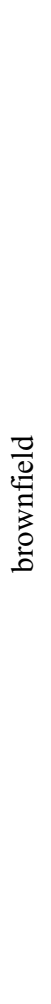 } & $\begin{array}{l}\text { Area of } \\
\text { the } \\
\text { building } \\
27545 \\
\mathrm{~m} 2\end{array}$ & $\begin{array}{l}\text { - } 35.7 \mathrm{~km} \text { to the station } \\
\text { "Chernikovskaya" of the } \\
\text { Kuibyshev Railway } \\
\text { - } 48 \mathrm{~km} \text { to the federal } \\
\text { highway M-7 } \\
\text { "Volga" } \\
-3.29 \mathrm{~km} \text { to the highway R- } \\
315 \text { "Ufa-Perm" } \\
\text { - } 73 \mathrm{~km} \text { to the International } \\
\text { Airport "Ufa" } \\
-12 \mathrm{~km} \text { to the river port of } \\
\text { Blagoveshchensk } \\
\text { - } 34 \mathrm{~km} \text { to the river port of } \\
\text { Ufa }\end{array}$ & $\begin{array}{l}\text { - heat supply - } \\
2,4 \text { Gcal / hour } \\
\text { - electric power } \\
\text { supply - 2,6 MW } \\
\text { - water supply - } \\
\text { 13,445 cub.m / } \\
\text { hour } \\
\text { - steam supply } \\
\text { - centralized } \\
\text { sewerage, } \\
\text { wastewater } \\
\text { treatment plants }\end{array}$ \\
\hline 4 & $\begin{array}{l}\text { Industrial park } \\
\text { "Building } \\
\text { materials of } \\
\text { Bashkortostan", } \\
\text { town of Agidel }\end{array}$ & & $\begin{array}{l}223,88 \\
\text { ha } \\
\text { There } \\
\text { are } 72 \\
\text { buildings } \\
\text { within } \\
\text { the } \\
\text { industrial } \\
\text { park } \\
\text { with a } \\
\text { total area } \\
\text { of } 113 \\
051,6 \\
\text { m2. }\end{array}$ & $\begin{array}{l}\text { - access railway Neftekamsk- } \\
\text { Agidel } \\
\text { - on-site railways and roads } \\
\text { - } 90 \mathrm{~km} \text { to the federal } \\
\text { highway M-7 "Volga" }\end{array}$ & $\begin{array}{l}\text { - electric power } \\
\text { supply - } 28.5 \\
\text { MW } \\
\text { - gas supply - } 52 \\
\text { cub. m / day } \\
\text { - water supply - } \\
200 \text { cub. m / day }\end{array}$ \\
\hline
\end{tabular}

Recently, many regional authorities have been considering the development of industrial parks as one of the priorities in the management of a specific subject of the Federation. This is evidenced by the appearance of several regional laws in 2012, in 
particular in the Krasnodar Krai and the Voronezh Region, and the development of the bill "On Industrial Parks" in the Ivanovo Region.

\section{Discussions}

The interest of regional and local authorities in the creation of industrial parks is understandable since their successful development contributes to the inflow of investments, to the growth of tax revenues to budgets of all levels, to the creation of workplaces, and to the social stability. That is why the issue of cooperation of banks with industrial parks and their residents for the implementation of investment projects is very relevant now. In combination with the state guarantees provided by the regions for securing loan obligations, such cooperation increases the availability of financing for management companies and residents of industrial parks. As a result, the market gets a new impulse for its development (Figure 3).

The creation of an industrial park for its owners is first and foremost the facility management - the management of objects by a special form of outsourcing where the participating enterprises can benefit by the concentration of their core activities, defeating competitors in a variety of ways. Both synergy and economies of scale work here. When the infrastructure is capital-intensive, expenses on necessary services are reduced because enterprises are located compactly.

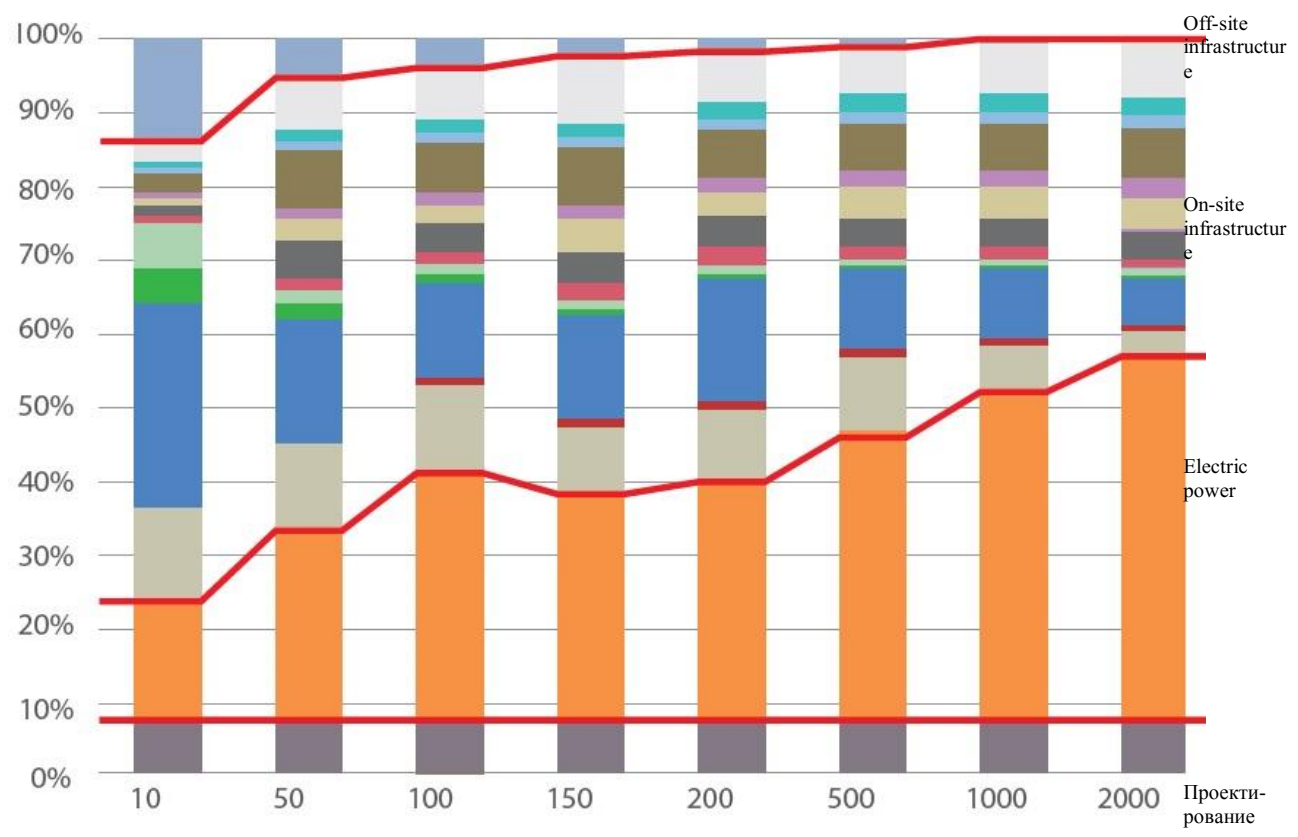

The area of the industrial park territory, ha

Off-site infrastructure

Road with hard surface

Underground power cable

Water pipes

Storm sewerage

Domestic sewage

Telecommunication networks

(Internet, telephone)

Street lighting

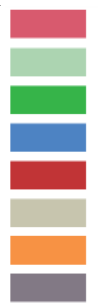

Gas pipeline

Water intake facility

Sewage pumping station

Storm water treatment facilities

Fire department

Office buildings

Required electricity generation capacity

Design cost 
Fig. 3. The ratio of cost elements in the construction of industrial park.

Experience shows that one of the main points for the development and filling of the park is the start of work of the first residents. To attract them, parks often offer preferential terms, including tax treatment. Moreover, many federal subjects of the Russian Federation have their own, regional, norms of legislation on granting tax preferences to investors. The volume of these preferences often depends on both the amount of investments in fixed assets and the priority of the investment project from the point of view of the development of the regional economy (Table 6, Table 7).

Table 6. Total and unit cost of construction of industrial park, taking into account designing.

\begin{tabular}{|l|l|l|l|l|l|l|l|l|}
\hline Area of territory, ha & 10 & 50 & 100 & 150 & 200 & 500 & 1000 & 2000 \\
\hline Total cost, million rubles & 206,7 & 477,7 & 715,2 & 1154,0 & 1484,5 & 2972,3 & 5349,7 & 9949,0 \\
\hline $\begin{array}{l}\text { Unit cost, million rubles / } \\
\text { ha }\end{array}$ & 20,7 & 9,6 & 7,2 & 7,7 & 7,4 & 5,9 & 5,3 & 5,0 \\
\hline
\end{tabular}

Table 7. Total and unit cost of creation of industrial park.

\begin{tabular}{|l|l|l|l|l|l|l|l|l|}
\hline Area of territory, ha & 10 & 50 & 100 & 150 & 200 & 500 & 1000 & 2000 \\
\hline Total cost, million rubles & 257,1 & 560,8 & 843,1 & 1322,2 & 1692,0 & 3379,8 & 6104,3 & 11358,6 \\
\hline $\begin{array}{l}\text { Unit cost, million rubles / } \\
\text { ha }\end{array}$ & 25,7 & 11,2 & 8,4 & 8,8 & 8,6 & 6,8 & 6,1 & 5,7 \\
\hline
\end{tabular}

Formation of a comprehensive strategy for the reorganization of industrial zones is provided by taking into account the following key principles [12]:

1. Selection of functions of a town - objects for removal, relocation and renewal;

2. Definition of decisions on places and methods of removal, relocation and renewal of functions of a town;

3. Decision-making on legal issues and financial plans for the removal, relocation and renewal of functions of a town;

4. Formation of plans for the interconnection of the removal, relocation and renewal of functions of a town and the provision of transport, logistics and communication infrastructure;

5. Formation of plans for consolidation of the relocated functions of a town and increasing their level.

Import substitution, on which industrialists began to orient, will become an important factor only after 2-3 years even at the high rates of project implementation, after the launch of at least a part of the planned projects. The expected trend of 2018 will be a sharp reduction in the volume of foreign investment in the industrial projects in Russia and a reduction in the percentage of foreign residents in the new industrial projects. The above mentioned trends suggest that the new year 2018 promises to be difficult and saturated, radically different from previous years both in terms of the composition of potential residents of industrial parks and changes in the sources and cost of financing of the new projects.

\section{Conclusion}

Import substitution will become an important factor only after 2-3 years even at the high rates of project implementation, after the launch of at least a part of the planned projects. So far, there have not been significant projects for the development of industrial parks in single industry towns (there are more than 300 single industry towns in Russia). Most probably, a decrease in investment activity will exacerbate the need for rapid re-industrialization of such towns. Industrial parks offering various formats of areas and support for small and 
medium-sized businesses are rare (Moscow region and Tatarstan), although their demand is unconditional.

Therefore, the analysis of the development and the social and economic importance of environmental industrial parks in Russia and abroad showed that, in park-type projects in general and in industrial park projects in particular, there is a great potential for positive impacts on the development of the territory on which the project is being implemented. These are an increase in the investment attractiveness of the territory for business, the formation of its industry specialization, stimulation of entrepreneurial activities, and improving the quality of life of the population.

\section{References}

1. P.I. Burak, I.A. Rozhdestvenskaya, I.M. Rukina, Osnovy ehkonomiki krupnogo goroda. Monografiya (Ekonomika, Moskva, 2009)

2. D.G. Sandler, P.D. Kuznecov, EHkonomika regiona 1, 76-88 (2015)

3. V.V. Filatov, A.E. Alekseev, Yu.V. Shlenov, D.I. Vorob'yov, A.Yu. Dorofeev, V.N. Dolgova, V.N. Zhenzhebir, T.S. Pshava, A.S. Fadeev, B.K. Fyodorov, A.V. Shestov, Mashinostroitel'nyj kompleks RF: otraslevye, regional'nye i strategicheskie aspekty razvitiya. Kollektivnaya monografiya (ZAO "Universitetskaya kniga", Kursk, 2017)

4. I.M. Rukina, V.V. Filatov, Kachestvo. Innovacii. Obrazovanie 5(96), 9-14 (2013)

5. B. Sychev, Osnovnye itogi issledovaniya mezhdunarodnyh i rossijskih praktik v oblasti sozdaniya i razvitiya industrial'nyh parkov (Associacii industrial'nyh parkov, Moscow, 2015)

6. I.M. Rukina, V.V. Filatov, Nauchnyj zhurnal NIU ITMO. Seriya: EHkonomika i ehkologicheskij menedzhment 2, 32 (2014)

7. I.V. Polozhenceva, V.V. Filatov, Vestnik Universiteta (Gosudarstvennyj universitet upravleniya) 16, 117-122 (2012)

8. O.A. Anichkina, A.O. Baranov, R.A. Zaplatin, N.V. Kapustina, V.A. Kozlov, G.M. Kolosova, B.L. Orlov, E.A. Pokidova, O.A. Sagina, A.L. Tatochenko, D.V. Tret'yak, G.V. Yazev, Importozameshchenie $i$ izderzhki obrashcheniya. Moskovskij gosudarstvennyj universitet tekhnologij i upravleniya imeni K. G. Razumovskogo (Pervyj kazachij universitet) (EHkonomika, Moskva, 2017)

9. V.P. Tret'yak, O.A. Sagina, Ekonomika i predprinimatel'stvo 10-2(75-2), 459-464 (2016) 